Article

\title{
The Performance and Adsorption Mechanism of a Novel Collector, Dodecyl Dimethyl Betaine (BS-12), for the Flotation Separation of Ilmenite and Titanaugite
}

\author{
Pan Chen ${ }^{1,2,3,4}$, Xujian Chai ${ }^{1}$, Mengjie Tian ${ }^{1}$, Wei Chen ${ }^{4}$, Si Wan ${ }^{4}$, Qingbo Meng ${ }^{2,3}$, \\ Jihua Zhai ${ }^{1,5, *}$ and Yude Gao ${ }^{2,3, *}$ \\ 1 School of Minerals Processing and Bioengineering, Central South University, Changsha 410083, China; \\ panchen@csu.edu.cn (P.C.); chaixujian@csu.edu.cn (X.C.); 155606018@csu.edu.cn (M.T.) \\ 2 Guangdong Institute of Resource Comprehensive Utilization, Guangzhou 510650, China; \\ 13202001016@163.com \\ 3 Guangdong Provincial Key Laboratory of Development and Comprehensive Utilization of Mineral \\ Resources, Guangzhou 510650, China \\ 4 Hunan Research Institute for Nonferrous Metals, Changsha 410100, China; cw_linglong@163.com (W.C.); \\ wanlion301@163.com (S.W.) \\ 5 School of Civil Engineering, University of Leeds, Leeds LS2 9JT, UK \\ * Correspondence: jihuazhai@csu.edu.cn (J.Z.); cmtougao@163.com (Y.G.)
}

Received: 25 December 2019; Accepted: 25 January 2020; Published: 29 January 2020

check for updates

\begin{abstract}
In this paper, a novel collector, dodecyl dimethyl betaine (BS-12), was used in the selective separation of ilmenite from titanaugite. The flotation performance and associated adsorption mechanism were studied by micro-flotation experiments, particle size analysis, Fourier-transform infrared (FT-IR) spectroscopy analysis, and X-ray photoelectron spectroscopy (XPS) analysis. The micro-flotation results indicated that BS-12 exhibited a stronger collecting ability towards ilmenite than titanaugite within an acidic $\mathrm{pH}$ range, and that the recovery of ilmenite was about $50 \%$ higher than that of titanaugite under the optimum flotation conditions. Particle size analysis demonstrated that BS-12 could selectively agglomerate ilmenite to a certain extent and then contribute to the flotation difference between ilmenite and titanaugite. FT-IR results showed some characteristic bands of BS-12 on treated ilmenite, and on titanaugite with BS-12. The XPS analysis further confirmed that BS-12 chemisorbed onto ilmenite and titanaugite in a similar way, but the limited active sites on titanaugite in comparison with ilmenite accounted for their differences in flotation.
\end{abstract}

Keywords: ilmenite; dodecyl dimethyl betaine; flotation separation; titanaugite; XPS

\section{Introduction}

In recent years, the titanium industry has become more and more important, due to the versatility of titanium and its derived compounds in aviation, navigation, medicine, metallurgy and other fields [1-4]. Globally, the main titanium resources with industrial utilization value to date, are ilmenite and rutile. Compared with ilmenite, rutile is more easily utilized and extracted from raw ores, which has consequently led to the depletion of large quantities of rutile; furthermore, rutile reserves are much lower than ilmenite reserves. Therefore, the future trend of titanium resource utilization will be largely reliant on ilmenite [5-7].

Due to different metallogenic mechanisms, it is more difficult to gain comparable benefits from igneous ilmenite ores in China, for example, than from sedimentary-type deposits, which are of higher 
grade, with gangues mainly being quartz [8]. In such cases where ilmenite-containing ores exist with characteristics such as low-grade quality, complex mineralogy and fine grains, it is difficult to achieve effective separation when using traditional physical separation methods such as gravity separation, high-intensity magnetic separation and electrical separation. Currently, flotation or its usage in combination with the above-mentioned techniques is mostly adopted for the selective separation of ilmenite from gangue minerals $[9,10]$.

At present, the main collectors that are being studied in ilmenite flotation are fatty acids or their salts [11-14]. However, one outstanding issue to be solved is that these collectors are not completely ionized, and they exist mostly in molecular forms under acidic conditions (the required $\mathrm{pH}$ range for practical yields from ilmenite), which generally leads to a low effectiveness of collector species in solution, and thus a lower recovery rate or a higher rate of collector consumption in flotation. Another problem associated with fatty acid-based collectors are their poor performance under low temperatures and with hard water. Hence, it is important to develop effective collectors that are suitable for strengthening ilmenite floatability, especially within acidic $\mathrm{pH}$ pulps [15].

Dodecyl dimethyl betaine (BS-12, $\mathrm{C}_{12} \mathrm{H}_{25} \mathrm{~N}^{+}\left(\mathrm{CH}_{3}\right)_{2} \mathrm{CH}_{2} \mathrm{COO}^{-}$) is a mild zwitterionic surfactant with resistance to hard water, and good stability under acid and alkali conditions. It has also been reported to be easily degraded, environmentally friendly and to have good foaming abilities, and therefore it is widely used as a detergent, dispersant and emulsifier because of its good compatibility and synergistic effects [16-19]. In the present study, BS-12 was first introduced as the collector in an ilmenite flotation system, in the hope of addressing the above-mentioned defects arising to some extent from fatty acid-based collectors. Its associated mechanisms were investigated by micro-flotation experiments, particle size analysis, Fourier-transform infrared (FT-IR) spectroscopy analysis and X-ray photoelectron spectroscopy (XPS) analyses.

\section{Materials and Methods}

\subsection{Materials and Reagents}

The ilmenite and titanaugite used in this study were obtained from Panzhihua, Sichuan province, China. The hand-picked samples were crushed and ground in a laboratory porcelain mill with an agate ball. Then, impurities were removed by repeated low-intensity magnetic separation, high-intensity magnetic separation, and gravity separation. Sequentially, samples in the $-0.074+0.038 \mathrm{~mm}$ size fraction were screened out for the flotation experiment. The purities of ilmenite and titanaugite were qualified on the basis of the result of X-ray diffraction (XRD) in Figure 1, and they met the criteria for micro-flotation.
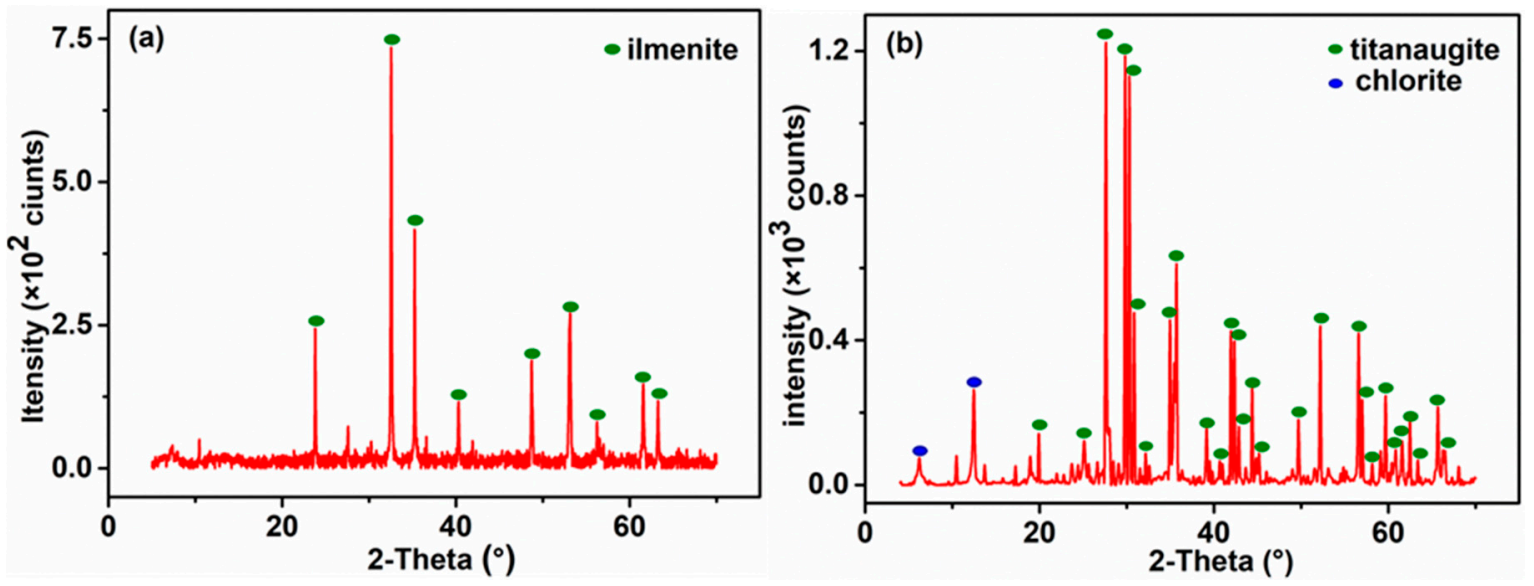

Figure 1. XRD spectra of ilmenite (a) and titanaugite (b). 
A BS-12 solution, prepared with a solid content of 30\% $(w / w)$ in deionized water, was used as the collector in the micro-flotation experiment, and pure BS-12 was purchased from Saen Chemical Technology Co., Ltd., Shanghai, China. The chemical structure and equilibrium reaction of BS-12 in an aqueous solution are shown in Figure 2. As seen in Figure 2, when $\mathrm{pH}<4.9$, BS-12, which is positively charged under this condition, was the cationic collector, while when $\mathrm{pH} \geq 4.9$, BS-12 was ionized to form a zwitterionic collector [19]. $\mathrm{HCl}$ and $\mathrm{NaOH}$ solutions were used to adjust the $\mathrm{pH}$ of the aqueous suspensions in the experiments, and distilled water was used throughout all experiments.

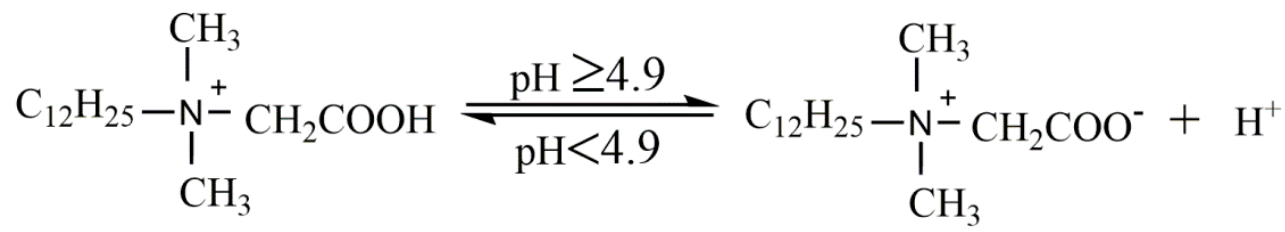

Figure 2. Chemical equilibrium reaction of BS-12 in aqueous solution.

\subsection{Flotation Tests}

Flotation tests were carried out by using a XFG-1600-type flotation machine (Prospecting Machinery Factory, Jilin, China; mechanical agitation) with a $40 \mathrm{~mL}$ Plexiglass cell and a spindle speed of 1650 rpm. Two grams of the purified mineral particles was added to the flotation cell filled with $35 \mathrm{~mL}$ distilled water in each flotation experiment. The desired amount of collector was added and agitated for $3 \mathrm{~min}$ after the $\mathrm{pH}$ of the suspension was adjust to the required value. The flotation was conducted for $4 \mathrm{~min}$. The froth products and tailings were weighed after filtering and drying, respectively, to calculate the flotation recovery. Three independent measurements of the flotation tests, run at each condition, were conducted, and the average value was presented.

\subsection{Particle Size Analysis}

The particle size test was performed by using a Mastersizer 2000 particle size analyzer (Malvern Instruments, London, UK). Two grams of purified mineral particles was added to a flotation cell containing $35 \mathrm{~mL}$ of deionized water, then stirred for $5 \mathrm{~min}$ at the optimal $\mathrm{pH}$ and reagent dosage for flotation experiments, and then the slurry was transferred to a beaker filled with $1 \mathrm{~L}$ deionized water for particle size testing. In the process of the particle size test, the spindle speed of the particle size analyzer was set to the same as that of the flotation machine, so that the hydrodynamic conditions generated by the two kinds of equipment were consistent. Several repeated tests were conducted, and the results showed good reproducibility.

\subsection{FT-IR Spectroscopy Measurements}

The FT-IR spectra were obtained by a Bruker Alpha (Waltham, MA, USA) FT-IR spectrophotometer, using the $\mathrm{KBr}$ disk technique. Two grams of pure minerals, ground to $2 \mu \mathrm{m}$ were added to $100 \mathrm{~mL}$ $0.1 \mathrm{M}$ BS-12 solution. After stirring for $30 \mathrm{~min}$, during which the $\mathrm{pH}$ of suspension was monitored continuously, the mineral particles were washed four times with distilled water of the same $\mathrm{pH}$ during filtration, and dried at room temperature under vacuum conditions for $24 \mathrm{~h}$. Then, the infrared adsorption spectrum was recorded from $400 \mathrm{~cm}^{-1}$ to $4000 \mathrm{~cm}^{-1}$.

\subsection{XPS Experiments}

The XPS analyses were carried out using a Thermo ESCALAB 250XI instrument (Thermo Fisher Scientific, Waltham, MA, USA) with $\mathrm{Al} \mathrm{K} \alpha$ as the sputtering source, at $16 \mathrm{kV}$ and $14.9 \mathrm{~mA}$. The vacuum pressure of the analytical chamber was about $10^{-9} \mathrm{~Pa}$. All binding energies were referenced to the neutral C1 s peak at $284.8 \mathrm{eV}$, to compensate for surface-charging effects. The preparation of the sample for XPS measurements was similar to the flotation test, and the collector dosage was kept at the same level of micro-flotation $\left(6.0 \times 10^{-5} \mathrm{~mol} / \mathrm{L}\right)$. The mineral sample was conditioned for $3 \mathrm{~min}$ with the 
collector after the $\mathrm{pH}$ was adjusted to the desired value. Then, the sample was filtered and washed four times with distilled water of the same $\mathrm{pH}$. The washed sample was dried under vacuum conditions at $40{ }^{\circ} \mathrm{C}$.

\section{Results and Discussion}

\subsection{Micro-flotation Analysis}

Figure 3 shows the flotation recovery of ilmenite and titanaugite as a function of $\mathrm{pH}$. As observed, the recovery of ilmenite increased slightly with the increase of $\mathrm{pH}$ from $\mathrm{pH} 4$, and it reached a maximum at $\mathrm{pH}$ 6. The flotation behavior of ilmenite deteriorated greatly at $\mathrm{pH}>9$, and this may have been due to the increased degree of hydroxylation on the ilmenite surface within this $\mathrm{pH}$ range, which could hinder the adsorption of the BS-12 species onto the ilmenite surface [20,21]. Ilmenite showed a good degree of floatability at $\mathrm{pH} 4-5$, and the foaming ability of BS-12, and the selective flocculation of ilmenite may be the main reasons for this result [18]. Comparatively, the recovery of titanaugite decreased continuously over the entire $\mathrm{pH}$ range. A pH range of 4 to 6 may thus be the optimum $\mathrm{pH}$ range for the separation of ilmenite from titanaugite when using BS-12 as the collector.

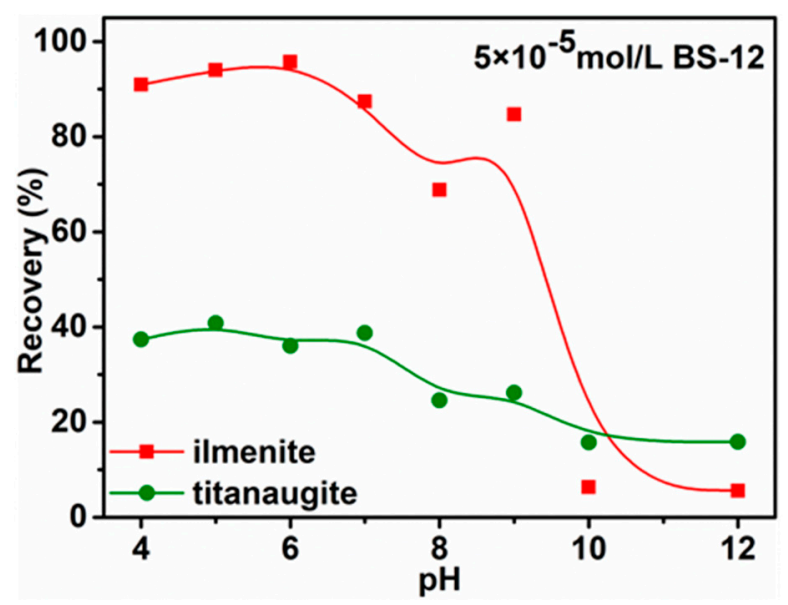

Figure 3. Flotation recovery of ilmenite and titanaugite as a function of $\mathrm{pH}$.

Figure 4 displays the flotation recovery rates of ilmenite and titanaugite as a function of the BS-12 concentration at $\mathrm{pH}$ 6. With the increase of BS-12 concentration, the recovery of ilmenite increased correspondingly, and it reached over $90 \%$ at a concentration of $6.0 \times 10^{-5} \mathrm{~mol} / \mathrm{L}$, after which the influence of increasing BS-12 dosage on ilmenite recovery became limited. Hence, $6.0 \times 10^{-5} \mathrm{~mol} / \mathrm{L}$ of BS-12 was used as the optimum concentration in the subsequent experiments. The recovery of titanaugite did not change significantly with an increasing concentration of BS-12, and the maximum recovery rate was only $40 \%$. The significant difference in recovery between ilmenite and titanaugite, as shown in Figures 3 and 4, indicated the selectivity of BS-12 in the flotation separation of ilmenite from titanaugite (especially within an acidic $\mathrm{pH}$ range), showing the preferential adsorption of BS-12 on an ilmenite surface compared to titanaugite. 


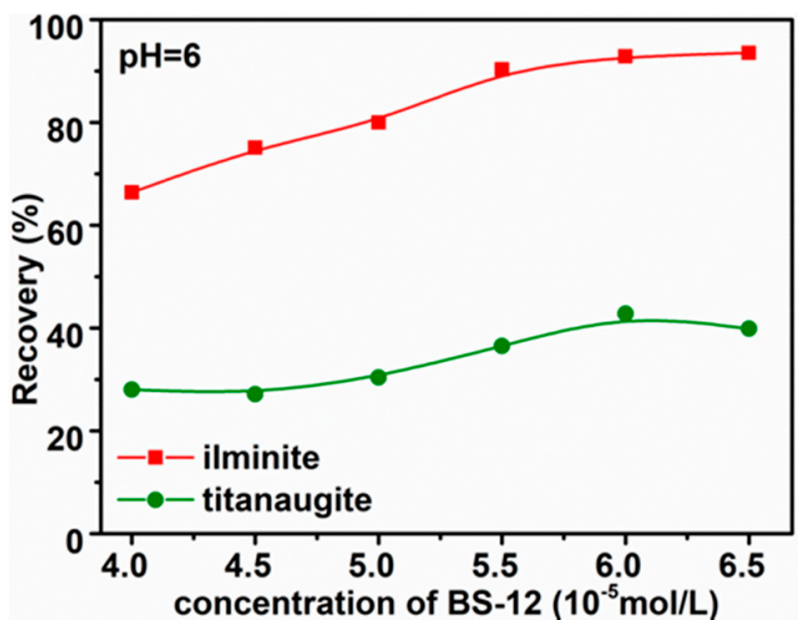

Figure 4. Flotation recovery rates of ilmenite and titanaugite as a function of BS-12 concentration at pH 6.

The results of the single mineral flotation experiments showed that BS-12 may produce excellent selective separation of ilmenite from titanaugite. Flotation tests of synthetic mixtures of mineral samples were performed to further evaluate the selectivity of BS-12. Figure 5 shows the flotation index of synthetic mixtures of mineral samples $\left(21.2 \% \mathrm{TiO}_{2}\right)$ by one roughing flotation, using BS-12 as the collector, at different $\mathrm{pH}$ values. As seen in Figure 5, the grade of $\mathrm{TiO}_{2}$ was more than $30 \%$, with high recoveries with an acidic slurry, indicating that $\mathrm{TiO}_{2}$ was enriched in the concentrate. This reflected that BS-12 was selective in the flotation separation of ilmenite from titanaugite, and that good flotation indexes could be obtained under acidic conditions.

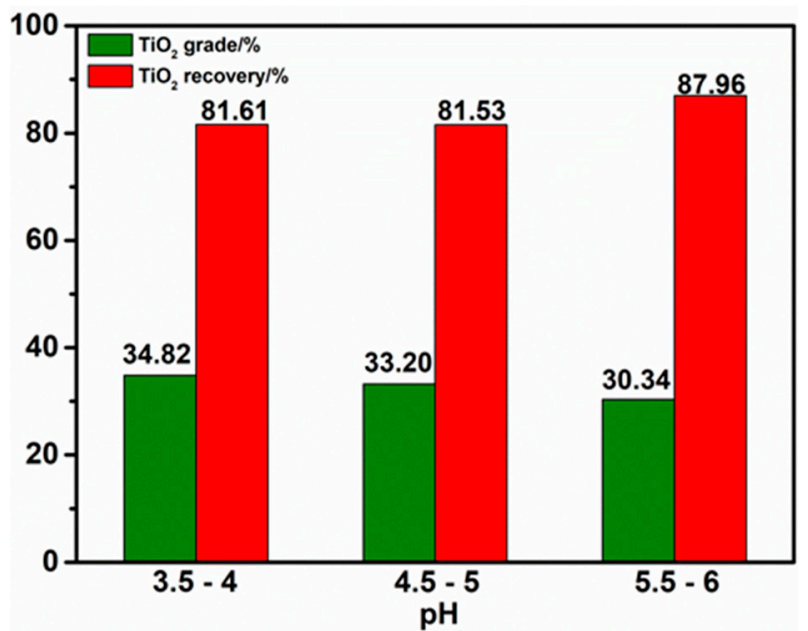

Figure 5. Flotation indexes of synthetic mixtures of minerals $\left(21.2 \% \mathrm{TiO}_{2}\right)$ using BS-12 $\left(6.0 \times 10^{-5} \mathrm{~mol} / \mathrm{L}\right)$ as the collector, at different $\mathrm{pH}$ values.

\subsection{Particle Size Analysis}

Figure 6 shows the particle size changes of ilmenite and titanaugite samples before and after treatment with BS-12. It can be seen from Figure 6a that the particle size of the ilmenite sample increased significantly after treatment with BS-12: the $d(50)$ and $d(90)$ of the ilmenite particles were $69.789 \mu \mathrm{m}$ and $107.13 \mu \mathrm{m}$ before treatment with BS-12, while the $\mathrm{d}(50)$ and $\mathrm{d}(90)$ of the ilmenite particles were $76.144 \mu \mathrm{m}$ and $132.076 \mu \mathrm{m}$, respectively, after treatment with BS-12. The $d(50)$ and $d(90)$ of the ilmenite particles increased by $6.355 \mu \mathrm{m}$ and $24.914 \mu \mathrm{m}$, respectively, which may have been due to a certain degree of hydrophobic agglomeration forming between the ilmenite particles treated with BS-12. This could have made the ilmenite particles more easily floated out, resulting in a higher 
flotation recovery. Comparatively, it can be seen from Figure $6 \mathrm{~b}$ that there was no obvious change in the particle size of the titanaugite sample before and after treatment with BS-12. It can be thus inferred that BS-12 induced the selective agglomerate of ilmenite particles, and this may have been a potential reason for the difference in the flotation recovery rates between ilmenite and titanaugite.
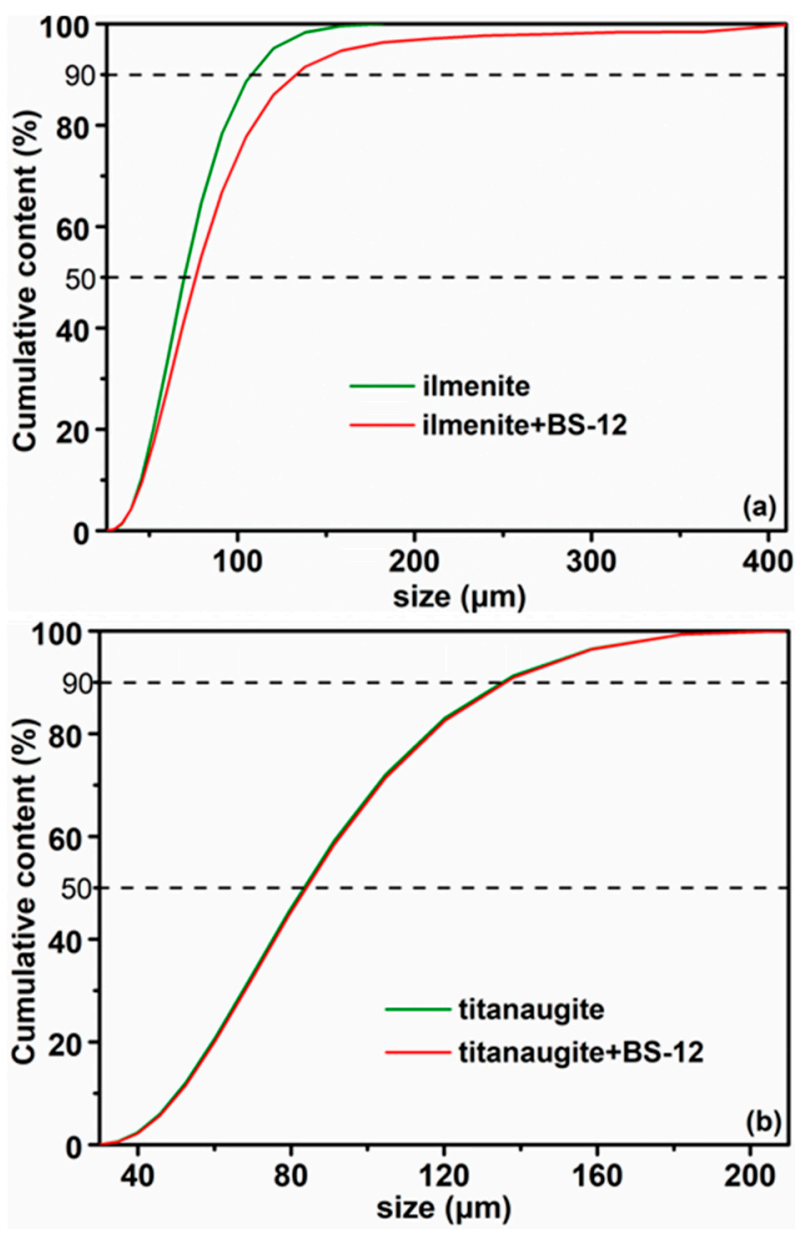

Figure 6. Particle size distributions of ilmenite (a) and titanaugite $(\mathbf{b})$ in the absence and presence of BS-12 (c $\left.=6.0 \times 10^{-5} \mathrm{~mol} / \mathrm{L}\right)$ at $\mathrm{pH} 6$.

\subsection{FT-IR Spectra Analysis}

Table 1 displays the characteristic bands of the FT-IR spectra of BS-12. The peaks at around 2920, 1457 and $1350 \mathrm{~cm}^{-1}$ were attributed to $\mathrm{C}-\mathrm{H}$ stretching, $\mathrm{C}-\mathrm{H}$ bending and $\mathrm{C}-\mathrm{H}$ rocking vibration absorption, respectively. The peaks of C-N stretching vibration absorption appeared at around 1457 and $1072 \mathrm{~cm}^{-1}$. The peaks at around 1631 and $1600 \mathrm{~cm}^{-1}$ were assigned to $\mathrm{C}=\mathrm{O}$ functional group stretching vibrations. The characteristic absorption peak of $\mathrm{O}-\mathrm{H}$ of the carboxyl group appeared at around $3368 \mathrm{~cm}^{-1}[19,22,23]$.

Table 1. The analysis of the FT-IR spectra results of BS-12.

\begin{tabular}{cc}
\hline Functional Group & Wavenumbers $\mathbf{( c m}^{-\mathbf{1}} \mathbf{)}$ \\
\hline C-H & 2920,1457 and 1350 \\
C-N & 1457 and 1072 \\
C $=\mathrm{O}$ & 1631 and 1600 \\
O-H & 3368 \\
\hline
\end{tabular}


Figure 7 shows the FT-IR spectra of ilmenite and titanaugite, before and after treatment with BS-12. BS-12 adsorbed relatively more easily on both ilmenite and titanaugite, as demonstrated by the appearance of new $-\mathrm{CH} 3$ and $-\mathrm{CH} 2-$ bands for treated ilmenite and titanaugite. However, the characteristic bands of the carboxyl group were not found in the present study. To further verify the adsorption behavior (physical or chemical) of BS-12 onto the ilmenite surface, XPS tests were conducted for clarification.
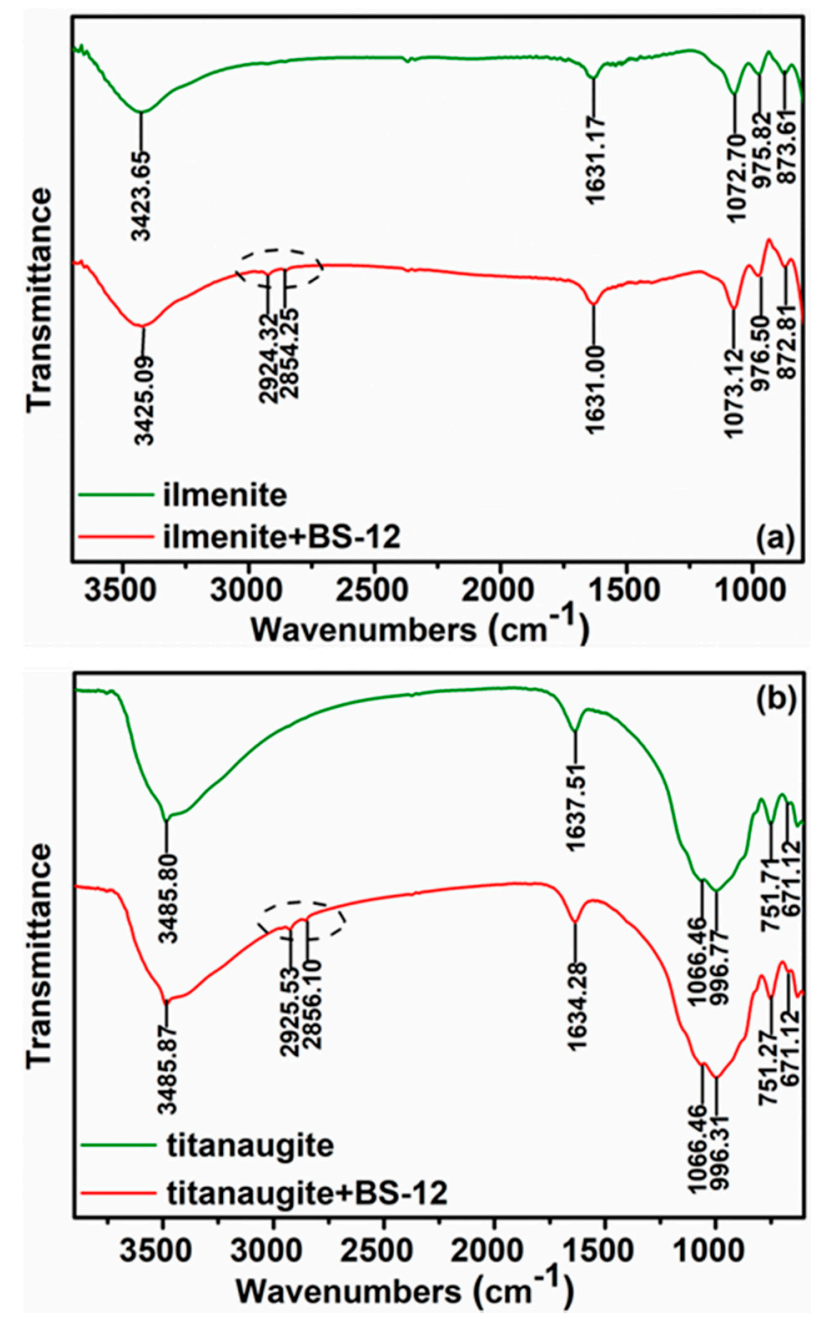

Figure 7. FT-IR spectra of ilmenite (a) and titanaugite (b) before and after the addition of BS-12.

\subsection{XPS Analysis}

The results of the particle size analysis showed that BS-12 can make ilmenite particles display hydrophobic agglomeration to a certain degree, but the same effect does not occur between titanaugite particles. The results of the FT-IR analysis indicated that BS-12 could adsorb onto the ilmenite and titanaugite surface, but the associated adsorption mechanism was still unclear. XPS tests were thus used to further explore the potential reaction mechanisms between BS-12 and ilmenite/titanaugite.

Table 2 gives details about the changes in binding energy and in the relative contents of different elements on the ilmenite surface, before and after BS-12 treatment. The binding energy changes indicated that the chemical environments of titanium and iron on the ilmenite surface had changed with the addition of BS-12, showing that chemisorption had occurred. The reduced relative contents of titanium and iron further confirmed that titanium and iron on the ilmenite surface both acted as active sites when using BS-12 as the collector. After treatment with BS-12, N was detected on ilmenite surface, and this also supported the adsorption of BS-12 on the ilmenite surface. 
Table 2. Binding energies and relative content changes of different elements on the ilmenite surface, before and after BS-12 treatment.

\begin{tabular}{|c|c|c|c|c|c|c|}
\hline \multirow{2}{*}{ Item } & \multicolumn{3}{|c|}{ Binding Energy (eV) } & \multicolumn{3}{|c|}{ Relative Content (\%) } \\
\hline & Without BS-12 & With BS-12 & Change & Without BS-12 & With BS-12 & Change \\
\hline C1s & 284.8 & 284.8 & 0 & 19.45 & 21.85 & +2.4 \\
\hline $\mathrm{Ti} 2 \mathrm{p}$ & 458.5 & 458.3 & 0.2 & 8 & 7.45 & -0.55 \\
\hline O1s & 530.6 & 530.4 & -0.2 & 62.65 & 59.99 & -2.66 \\
\hline $\mathrm{Fe} 2 \mathrm{p}$ & 711.3 & 711 & -0.3 & 9.9 & 9.57 & -0.33 \\
\hline N1s & - & 402.4 & - & 0 & 1.14 & +1.14 \\
\hline
\end{tabular}

A peak-fitting analysis was further conducted, to explore the potential adsorption of BS-12 onto the ilmenite surface, and Figure 8 shows the results of the high-resolution spectra of $\mathrm{Fe} 2 \mathrm{p} 3 / 2$ before and after BS-12 treatment. As shown in Figure 8a, iron on a pure ilmenite surface was composed of ferrous and ferric species, at about $711 \mathrm{eV}$ and $713.1 \mathrm{eV}$, respectively [24,25]. As for the iron on the ilmenite surface treated with BS-12, the peaks at $710.7 \mathrm{eV}$ and 712.7 were assigned to ferrous and ferric species, respectively, with both showing a decrease in binding energies $(-0.3 \mathrm{eV}$ for ferrous and $-0.4 \mathrm{eV}$ for ferric). This demonstrated the changes in their respective chemical environments, and that both ferrous and ferric species can react with BS-12 via chemisorption. Furthermore, the change in the ferric species was much more obvious than that of the ferrous species, and this showed that the ferric species were much more easily served as active sites compared with the ferrous species, which was in agreement with previous findings from ilmenite flotation showing that ferric species can form less soluble complexes with the collector than can ferrous species $[26,27]$.
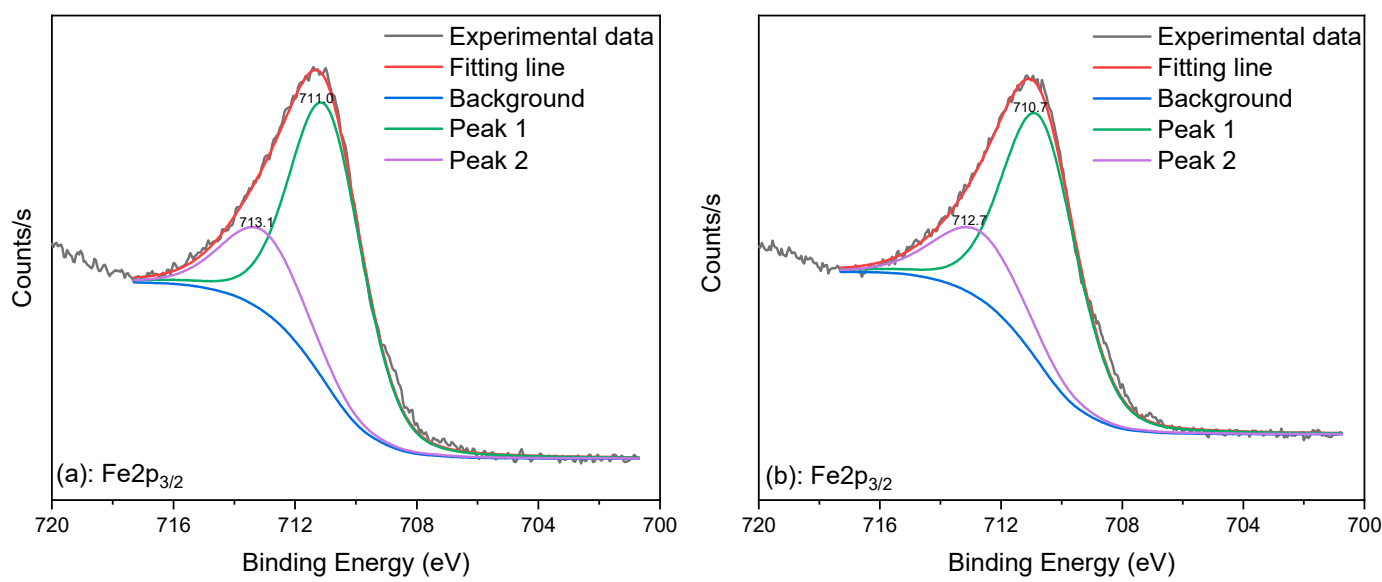

Figure 8. High resolution spectra of Fe2p3/2: (a) pure ilmenite; (b) pure ilmenite+BS-12.

Figure 9 displays the peaking-fitting results of the high-resolution spectra of Ti2p3/2 in the absence and presence of BS-12. Figure 9a showed that titanium on a pure ilmenite surface consisted of Ti-O-Ti and Ti-O-Fe linkages at about $458.2 \mathrm{eV}$ and $458.8 \mathrm{eV}$, respectively $[28,29]$. After treatment with BS-12, as shown in Figure 9b, the Ti2p3/2 peaks of the Ti-O-Ti and Ti-O-Fe linkages shifted by $0.1 \mathrm{eV}$ and $0.2 \mathrm{eV}$, respectively to lower binding energies. It seemed that the presence of iron enhanced the potential of titanium as the active site to some extent. Together with Table 2, this also confirmed that as the active sites, titanium on an ilmenite surface mainly reacted with BS-12 via chemisorption, which was similar to iron on an ilmenite surface. 

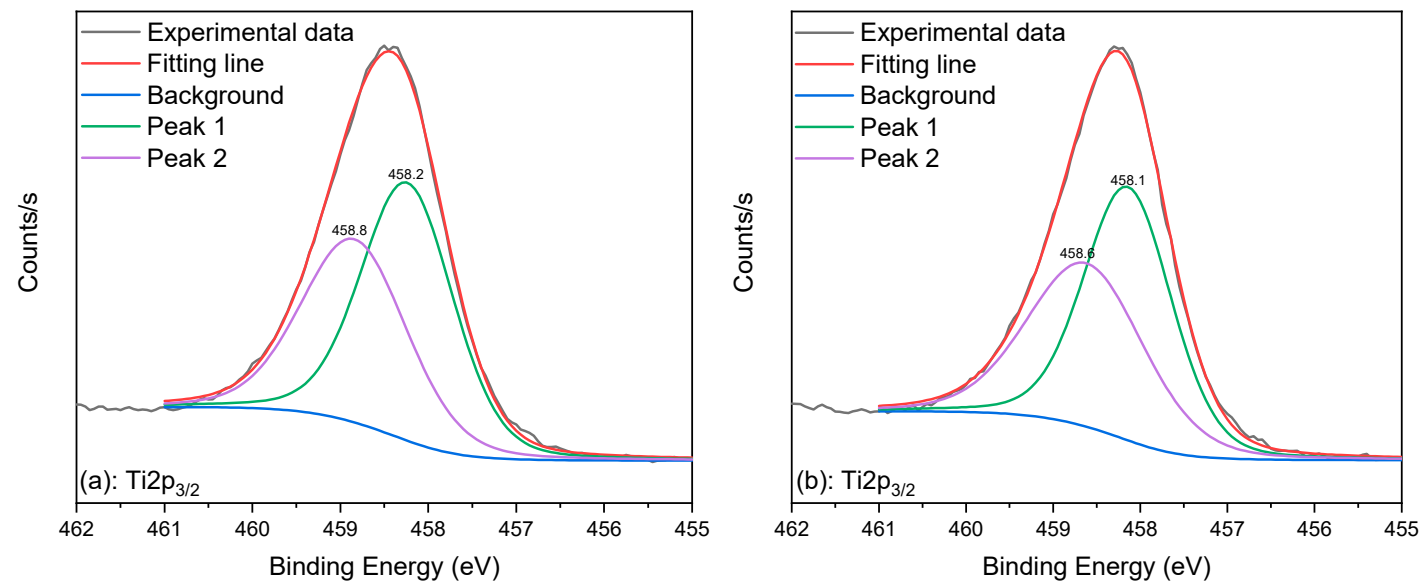

Figure 9. High-resolution spectra of Ti2p3/2: (a) pure ilmenite; (b) pure ilmenite + BS-12.

As for pure titanaugite, the relative contents of $\mathrm{C}, \mathrm{Ti}, \mathrm{O}$ and Fe on its surface, as detected by XPS, were $21.05 \%, 0.13 \%, 71.37 \%$ and $7.45 \%$, respectively. In view of the low relative content of Ti on the titanaugite surface, Ti could play a limited role even as a potential active site on the titanaugite surface (the XPS test showed that the shift in binding energy was $0.2 \mathrm{eV}$ after treatment with BS-12). As for iron on a titanaugite surface, its Fe2p spectra before and after BS-12 treatment are shown in Figure 10. The associated binding energy shift of iron was $-0.5 \mathrm{eV}$, and this indicated a change in its chemical environment. It was inferred that BS-12 can also chemisorb onto a titanaugite surface via titanium and iron as the active sites, but that this process is not effective as its adsorption onto an ilmenite surface, because of the limited contents of titanium and iron on the titanaugite surface. This would be the reason why BS-12 had preferential adsorption onto ilmenite rather than titanaugite, which agreed well with the results of the micro-flotation tests.

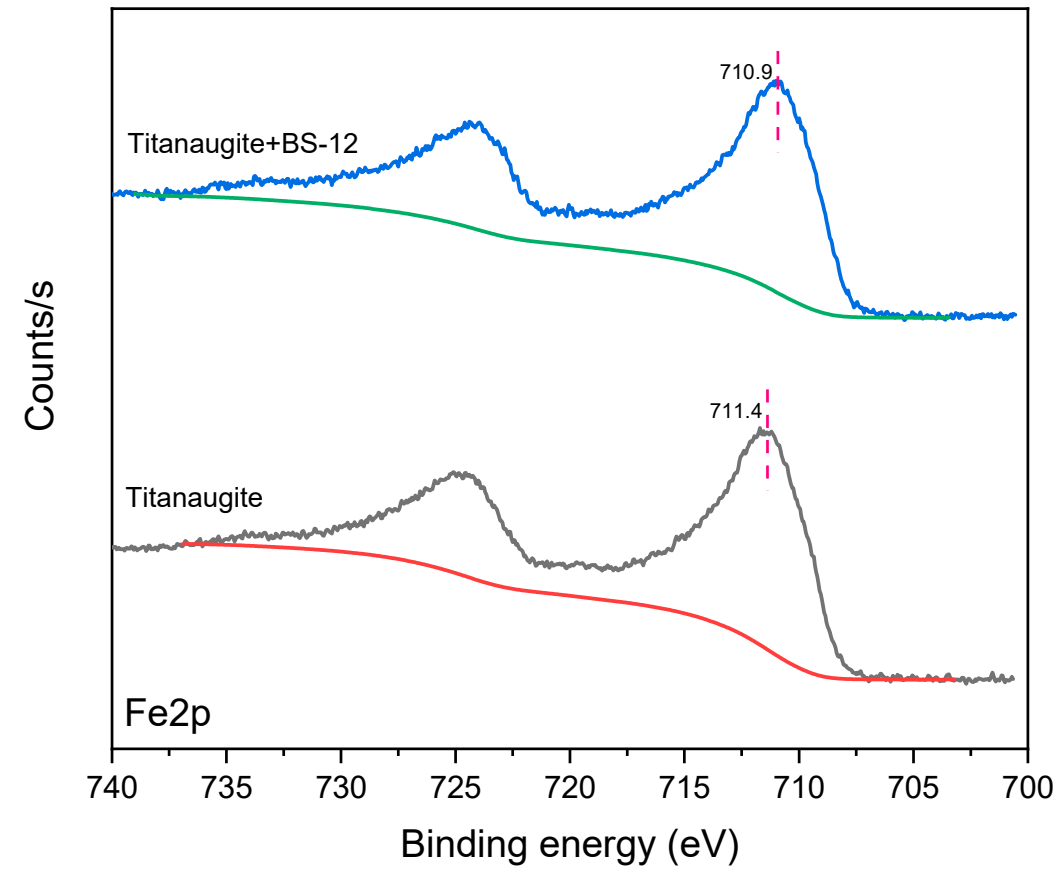

Figure 10. High-resolution spectra of Fe2p, before and after BS-12 treatment.

\section{Conclusions}

This paper studied the performance of BS-12 as a collector in the flotation separation of ilmenite from titanaugite. Micro-flotation experiments indicated that BS-12 exhibited a stronger collecting 
ability towards ilmenite than titanaugite, and that the optimum $\mathrm{pH}$ range for ilmenite flotation was from 4 to 6 . The results of the particle size analysis showed that BS-12 can make ilmenite particles perform a certain degree of hydrophobic agglomeration, which made it easier to float out, but that it fails to have the same effect for titanaugite particles, resulting in a flotation difference between ilmenite and titanaugite (in agreement with the flotation behavior). FT-IR tests showed that BS-12 could adsorb on both ilmenite and titanaugite. XPS tests further demonstrated that BS-12 species reacted with titanium and iron species on an ilmenite surface via chemisorption at the studied $\mathrm{pH}$, and that this behavior applied to titanaugite as well. However, because of the lower titanium and iron contents as active sites on the titanaugite surface in comparison with ilmenite, more BS-12 species can therefore adsorb onto ilmenite. Therefore, there may be two reasons for the flotation differences between ilmenite and titanaugite. One is that BS-12 selectively leads to the hydrophobic agglomeration of ilmenite, making it easier to be floated; the other is that compared with titanaugite, the surfaces of ilmenite particles have more active sites, and thus can adsorb more BS-12 species.

Author Contributions: P.C., X.C., and M.T. designed the experiments; X.C. and M.T. performed the experiments and analyzed the data; W.C. and S.W. contributed reagents; Q.M. and Y.G. funded the research; X.C. and J.Z. wrote the paper. All authors have read and agreed to the published version of the manuscript.

Funding: The authors acknowledge the support of China Postdoctoral Science Foundation, China (2019M650188), the Hunan Natural Science Foundation for the youth, China (2018JJ3665), Science and Technology Planning Project of Guangdong Province of China (No. 2017B030314046), the National Science and Technology Support Program of China (2015BAB19B01), and the Key Laboratory of Hunan Province for Clean and Efficient Utilization of Strategic Calcium-containing Mineral Resources, China (2018TP1002).

Conflicts of Interest: The authors declare no conflict of interest.

\section{References}

1. Niinomi, M. Recent research and development in titanium alloys for biomedical applications and healthcare goods. Sci. Technol. Adv. Mater. 2003, 4, 445-454. [CrossRef]

2. Wang, X.; Zhao, Y.; Wang, Y.; Hou, H.; Zeng, W. Kinetics of hydrogen absorption/desorption in TC21 alloy. J. Alloys Compd. 2010, 490, 562-567. [CrossRef]

3. Zhang, Y.; Wang, L.; Sun, W.; Hu, Y.; Tang, H. Membrane technologies for $\mathrm{Li}^{+} / \mathrm{Mg}^{2+}$ separation from salt-lake brines and seawater: A comprehensive review. J. Ind. Eng. Chem. 2020, 81, 7-23. [CrossRef]

4. Zhang, Y.; Hu, Y.; Sun, N.; Khoso, S.A.; Wang, L.; Sun, W. A novel precipitant for separating lithium from magnesium in high $\mathrm{Mg} / \mathrm{Li}$ ratio brine. Hydrometallurgy 2019, 187, 125-133. [CrossRef]

5. Fan, X.; Rowson, N.A. The effect of $\mathrm{Pb}\left(\mathrm{NO}_{3}\right)_{2}$ on ilmenite flotation. Miner. Eng. 2000, 13, 205-215. [CrossRef]

6. Samal, S.; Mohapatra, B.K.; Mukherjee, P.S.; Chatterjee, S.K. Integrated XRD, EPMA and XRF study of ilmenite and titania slag used in pigment production. J. Alloys Compd. 2009, 474, 484-489. [CrossRef]

7. Zhang, Y.; Hu, Y.; Sun, N.; Liu, R.; Wang, Z.; Wang, L.; Sun, W. Systematic review of feldspar beneficiation and its comprehensive application. Miner. Eng. 2018, 128, 141-152. [CrossRef]

8. Woodruff, L.G.; Bedinger, G.M.; Piatak, N.M. Titanium; 1802T; U.S. Geological Survey: Reston, VA, USA, 2017; p. 36.

9. Bulatovic, S.; Wyslouzil, D.M. Process development for treatment of complex perovskite, ilmenite and rutile ores. Miner. Eng. 1999, 12, 1407-1417. [CrossRef]

10. Zhang, X.; Liu, D.; Fang, J.; Xu, J. Study on Influence of Residual Magnetite in Panzhihua Ilmenite Flotation. Procedia Earth Planet. Sci. 2011, 2, 83-88. [CrossRef]

11. Chen, P.; Zhai, J.H.; Sun, W.; Hu, Y.H.; Yin, Z.G. The activation mechanism of lead ions in the flotation of ilmenite using sodium oleate as a collector. Miner. Eng. 2017, 111, 100-107. [CrossRef]

12. Liu, X.; Xie, J.; Huang, G.; Li, C. Low-temperature performance of cationic collector undecyl propyl ether amine for ilmenite flotation. Miner. Eng. 2017, 114, 50-56. [CrossRef]

13. Mehdilo, A.; Irannajad, M.; Rezai, B. Chemical and mineralogical composition of ilmenite: Effects on physical and surface properties. Miner. Eng. 2015, 70, 64-76. [CrossRef]

14. Yang, Y.; Xu, L.; Tian, J.; Liu, Y.; Han, Y. Selective flotation of ilmenite from olivine using the acidified water glass as depressant. Int. J. Mineral Process. 2016, 157, 73-79. [CrossRef] 
15. Zhu, Y.-G.; Zhang, G.-F.; Feng, Q.-M.; Yan, D.-C.; Wang, W.-Q. Effect of surface dissolution on flotation separation of fine ilmenite from titanaugite. Trans. Nonferrous Metals Soc. China 2011, 21, 1149-1154. [CrossRef]

16. Hu, N.; Shu, T.; Wu, Z.; Liu, G.; Li, Z.; Zhao, Y.; Yin, H.; Huang, D. BS12-assisted flotation for the intensification of SNPs separation from CMP wastewater using a novel flotation column. J. Hazard Mater. 2018, 344, 788-796. [CrossRef]

17. Islam, K.N.; Ali, M.E.; Bakar, M.Z.B.A.; Loqman, M.Y.; Islam, A.; Islam, M.S.; Rahman, M.M.; Ullah, M. A novel catalytic method for the synthesis of spherical aragonite nanoparticles from cockle shells. Powder Technol. 2013, 246, 434-440. [CrossRef]

18. Liu, K.; Jiang, J.; Cui, Z.; Binks, B.P. pH-Responsive Pickering Emulsions Stabilized by Silica Nanoparticles in Combination with a Conventional Zwitterionic Surfactant. Langmuir 2017, 33, 2296-2305. [CrossRef]

19. Zhang, Z.; Wu, Z.; Liu, G. Interfacial adsorption of methyl orange in liquid phase of foam fractionation using dodecyl dimethyl betaine as the collector. J. Ind. Eng. Chem. 2015, 28, 184-189. [CrossRef]

20. Tian, M.; Gao, Z.; Khoso, S.A.; Sun, W.; Hu, Y. Understanding the activation mechanism of $\mathrm{Pb}^{2+}$ ion in benzohydroxamic acid flotation of spodumene: Experimental findings and DFT simulations. Miner. Eng. 2019, 143. [CrossRef]

21. Hu, Y.; He, J.; Zhang, C.; Zhang, C.; Sun, W.; Zhao, D.; Chen, P.; Han, H.; Gao, Z.; Liu, R.; et al. Insights into the activation mechanism of calcium ions on the sericite surface: A combined experimental and computational study. Appl. Surf. Sci. 2018, 427, 162-168. [CrossRef]

22. He, H.; Li, W.; Deng, H.; Ren, L.; Zhang, Y.; Zhu, L.; Xie, J.; Li, T. Surface characteristics of a recyclable and efficient adsorption material. Mater. Lett. 2019, 256. [CrossRef]

23. Islam, K.N.; Bakar, M.Z.B.A.; Ali, M.E.; Hussein, M.Z.B.; Noordin, M.M.; Loqman, M.Y.; Miah, G.; Wahid, H.; Hashim, U. A novel method for the synthesis of calcium carbonate (aragonite) nanoparticles from cockle shells. Powder Technol. 2013, 235, 70-75. [CrossRef]

24. Yamashita, T.; Hayes, P. Analysis of XPS spectra of $\mathrm{Fe}^{2+}$ and $\mathrm{Fe}^{3+}$ ions in oxide materials. Appl. Surf. Sci. 2008, 254, 2441-2449. [CrossRef]

25. Mills, P.; Sullivan, J.L. A study of the core level electrons in iron and its three oxides by means of X-ray. J. Phys. D Appl. Phys. 1983, 16, 723-732. [CrossRef]

26. Fan, X.; Waters, K.E.; Rowson, N.A.; Parker, D.J. Modification of ilmenite surface chemistry for enhancing surfactants adsorption and bubble attachment. J. Colloid Interface Sci. 2009, 329, 167-172. [CrossRef]

27. Fan, X.; Rowson, N. Fundamental Investigation of Microwave Pretreatment on the Flotation of Massive Ilmenite Ores. Dev. Chem. Eng. Miner. Process. 2008, 8, 167-182. [CrossRef]

28. Phoohinkong, W.; Pavasupree, S.; Mekprasart, W.; Pecharapa, W. Synthesis of low-cost titanium dioxide-based heterojunction nanocomposite from natural ilmenite and leucoxene for electrochemical energy storage application. Curr. Appl. Phys. 2018, 18, S44-S54. [CrossRef]

29. Miao, C.; Shi, T.; Xu, G.; Ji, S.; Ye, C. Photocurrent enhancement for Ti-doped $\mathrm{Fe}_{2} \mathrm{O}_{3}$ thin film photoanodes by an in situ solid-state reaction method. ACS Appl. Mater. Interfaces 2013, 5, 1310-1316. [CrossRef]

(C) 2020 by the authors. Licensee MDPI, Basel, Switzerland. This article is an open access article distributed under the terms and conditions of the Creative Commons Attribution (CC BY) license (http://creativecommons.org/licenses/by/4.0/). 